\title{
Sağlık ve Kültür İlişkisi Bağlamında Popüler Sağlık Dergilerinde Sağlığın Sunumu
}

\author{
Presentation of Health in Popular Health Magazines in the Context of the Relationship Between \\ Health and Culture
}

Eda Turancı, Dr. Öğr. Üyesi, Ankara Hacı Bayram Veli Üniversitesi İletişim Fakültesi, E-posta: edaturanci@hotmail.com Elif Eşiyok, Doç. Dr., Atılım Üniversitesi İşletme Fakültesi, E-posta: elif.esiyok@atilim.edu.tr

https://doi.org/10.47998/ikad.903290

Anahtar Kelimeler:

Sağlik,

Kültür,

Women's Health, Türkiye, Amerika Birleşik Devletleri.
Keywords:

Health,

Culture,

Women's Health,

Turkey,

United States of

America.
Öz

Dünya Sağlık Örgütü sağlık kavramını fiziksel, sosyal ve ruhsal olmak üzere üç boyutta tanımlamaktadır. Buna göre sağlık ve sağlıklı olma hali, bu üç unsurun bir arada bulunmasına işaret eden tam bir iyilik hali olarak açıklanmaktadır. Disiplinlerarası bir konu olan sağlığın tanımı, kültüre ve topluma göre şekillenebilmektedir. Bu noktadan hareketle bu çalışmanın amacı, popüler kültür ürünlerinden biri olan kadın dergilerinde sağlığın nasıl ele alındığını incelemektedir. Çalışmanın örneklemini Türkiye ve Amerika Birleşik Devletleri'nde yayınlanmış olan Women's Health dergisinin 2009-2019 yılları arasındaki tüm sayılarının kapakları oluşturmaktadır. Dergi kapakları içerik analizi yöntemi ile incelenmiştir. Bu inceleme sonucunda her iki ülkede de yayınlanan dergilerde sağlı̆̆ın daha çok fiziksel sağlık ve bedenin görünümü kapsamında ele alındığı, en az içeriğin sosyal sağlık ile ilgili olduğu, her iki ülkede fiziksel sağlık alt kategorisinde en çok "spor/egzersiz" içeriklerine yer verildiği saptanmıştır. Türkiye'de yayınlanan dergilerin kapaklarında Amerikalı ve Türklerin eşit sayıda yer aldığı, ancak Amerika'da yayınlanan sayılarda herhangi bir Türk kapak kızına yer verilmediği görülmüştür. Bu bağlamda popüler kültür ürünlerinin, kültürlerarası farklılıkları silikleştirdiğini söylemek mümkündür.

\section{Abstract}

The World Health Organization defines the concept of health in three dimensions as physical, mental, and social. Accordingly, the state of well-being occurs once these three dimensions are existed. The definition of health, which is an interdisciplinary subject, can be shaped according to culture and society. From this point of view, the purpose of this study is to examine how health is represented in women's magazines which is a product of popular culture. The sample of this study is the Women's Health magazine covers which is published between 2009-2019 in Turkey and United States of America. Magazine covers were examined with content analysis. As a result of this examination, it was determined that health is mostly discussed within the scope of physical health and appearance. Social health related topics are not covered as the other health dimension. The content of "sports/exercise" is mostly included in the physical health subcategory in both countries. In Turkish issues, the nationality of cover girls have an equal number of Americans and Turks. In contrary, no Turkish cover girls are seen in the issues published in United States. In this context, it is possible to say that popular culture products obscure the intercultural differences. 


\section{Giriș}

Dünya Sağlık Örgütü’nün tanımında karşımıza çıkan “tam bir iyilik hali” vurgusu, sağlığa bütüncül bir bakış açısı sunmaktadır. Fiziksel, ruhsal ve sosyal boyutları olan sağlik, toplumsal gerçekliğin içinde inşa edilmekte ve kültürel kodlardan etkilenmektedir. Buna göre sağlıklı birey algısı, toplumsal ve kültürel bir olgudur. Sağlık, yalnızca hastalıklar üzerinden açıklanabilir bir konu değildir ve MacLachlan'ın (2006: 21) ifade ettiği gibi, sağlıklı ile sağlıksız olmak arasında net bir çizgi olmamakla birlikte, "insanlar ve sağlıkları bundan daha karmaşıktır". Sağlıklı olma algısının pek çok belirleyicisi olmakla birlikte, kültür de bunlardan biridir. Bu bağlamda her toplumun kültürel yapısına göre o kültürdeki sağlı̆̆ı anlamlandırma süreçleri değișebilmektedir.

Kültürel farklılıkları tanımlamada Hofstede'nin sınıflandırması önemli bir çalışma olarak karşımıza çıkmaktadır. Hofstede çalışmasında, farklı kültürlerde yaşayan bireyleri, "güç mesafesi”, "belirsizliklerden kaçınma”, "bireysellik ve kolektivizm”, "maskülenlikdişilik", "uzun ve kısa vadeli düşünme" olmak üzere beş boyut altında incelemiştir (Hofstede, 2001). Hofstede'nin farklı ülkeleri incelediği çalışmasına bakıldığında, Amerika ve Türkiye arasında belirgin farklar dikkat çekmektedir. Farklı toplumların, toplum içindeki güç eşitsizliğine verdiği tepki ile bağlantılı olan güç mesafesinde Türkiye 18/19. ve Amerika 38. sirada yer almaktadır (Hofstede, 2001: 87). Bir kültürde yaşayan bireylerin, belirsizlik durumlarında kendilerini ne derecede tehdit altında hissettikleri ile ilgili olan belirsizliklerden kaçınma düzeyine bakıldığında, Türkiye 16/17. ve Amerika 43. sırada yer almaktadır (Hofstede, 2001: 151). Toplumdaki bireylerin birlikte yaşamaya ilişkin tutumlarını ortaya koyan bireysellik düzeyine bakıldığında ise, Amerika birinci sırada, Türkiye ise 28. sırada yer almaktadır (Hofstede, 2001: 215). Bireylerin yaşadıkları toplumdaki duygusal ve sosyal rollerine ilişkin yaklaşımlarını ortaya koyan maskülenlik düzeylerine bakıldığında, Türkiye 32/33. sırada yer alırken, Amerika 15. sırada yer almıştır (Hofstede, 2001: 286). Bu sıralamalardan da görüleceği gibi Türkiye güç mesafesi yüksek bir toplum iken, Amerika güç mesafesi düşük bir toplumdur. Belirsizlikten kaçınma eğilimi Türkiye'de yüksek iken, Amerika'da daha düşüktür. Türkiye kolektif toplum özelliği taşırken, Amerika bireysel bir toplumdur. Maskülenlik düzeyine bakıldığında ise, Türkiye daha maskülen, Amerika ise daha dişil bir toplumdur. Buna göre çalışmanın amacı, Hofstede'nin sınıflandırmasına dayanarak farklı kültürel yapılara sahip oldukları görülen Türkiye ve Amerika'da yayınlanan Women's Health dergilerinin kapaklarında yer alan başlıkların ve sağlık içeriklerinin incelenmesi ve kültürel bir perspektiften farklılıklar ile benzerliklerin ortaya çıkarılmaya çalışılmasıdır.

Öte yandan sağlık ve fitness dergilerinin beden memnuniyetsizliği ve psikolojik sağlık üzerine etkilerinin, genellikle erkekler üzerinden çalışılması ve kadınlar üzerine çok az sayıda çalışma olması (Swiatkowski, 2016) nedeniyle çalışmada, kadın dergilerinden biri olan Women's Health dergisi amaçlı olarak seçilmiştir. Bu doğrultuda Amerika ve Türkiye'de 2009 ile 2019 yılları arasında yayınlanmış olan tüm sayılar inceleme kapsamına alınmıştır. 


\section{Sağlığın Tanımı ve Boyutları}

Sağlık genellikle, fiziksel unsurlar ile bedenin işleyişi üzerinden açıklanan bir kavram olsa da, Dünya Sağlık Örgütü'nün 1948 yılından beri kullandığı tanımına göre sağlık, "yalnızca hastalığın ya da sakatlığın olmaması değil, aynı zamanda fiziksel, ruhsal ve sosyal olarak tam bir iyilik hali"dir (WHO, 2020a). Bu tanımdan da görülebileceği gibi sağlığın bedensel ve fiziksel bir unsur olmaktan öte daha geniş bir perspektiften değerlendirilmesi gerekmektedir. Sağlık hem pek çok faktörü etkileyen, hem de pek çok faktörden etkilenen bir durum olarak toplumsal, psikolojik, siyasal, ekonomik, çevresel ve kültürel açılardan da tartışılan bir konudur. Öte yandan Dünya Sağlık Örgütü’nün yapmış olduğu tanım sağlığı toplumsal bir bağlama oturtmaktadır ve ifade edildiği gibi bu tanım "sağlığı hastalığa indirgemekten kurtarmış, sağlığın korunması hatta geliştirilmesini öne çıkarmış ve bireyi değil toplumu merkeze alan toplumcu bir yaklaşım" (Ulutürk, 2015: 49) ortaya koymuştur.

Dünya Sağlık Örgütü’nün tanımından hareketle sağlığın üç boyutundan bahsetmek mümkündür. Fiziksel, ruhsal ve sosyal olarak sınıflandırılabilecek bu üç boyut, bireyin kendi sağlığına ilişkin sübjektif algılarına göre de değişebilmektedir. Aynı zamanda bu üç boyutun, birbiriyle doğrudan ilişkili olduğunu da belirtmek gerekir. Örneğin, fiziksel sağlığın bozulmasının ruhsal ve sosyal sağlık üzerinde de olumsuz etkileri olabileceği gibi, ruhsal sağlıkta bozulmalar da fiziksel sağlığı kötü etkileyebilmektedir.

Fiziksel sağlık, beden fonksiyonlarının sağlıklı olduğunu göstermektedir (Ulutürk, 2015, s. 50) ve biyomedikal bir çerçeveden vücudu, doku ve organların işleyişi üzerinden açıklamaktadır (Vingilis vd., 1998: 83). Koipysheva ve arkadaşları (2018: 603) fiziksel sağlığı dinamik bir durum olarak tanımlarken, kişinin "biyolojik, fizyolojik ve zihinsel işlevlerini, en uygun çalışma kapasitesi ve maksimum yaşam beklentisiyle sosyal aktiviteyi koruma ve geliştirme sürecini” tanımlamaktadırlar.

Sağlığı, yaşam kalitesini, yaşam süresini ve sağlık algısını olumlu ya da olumsuz yönden etkileyen çok sayıda faktör bulunmaktadır. Bunların başında fiziksel aktivite ve beslenme (Warburton vd., 2006; Miles, 2007; Korn, vd., 2013; Bulut, 2013), tütün ve alkol kullanımı (Sturm, 2002; Das, 2003), obezite başta olmak üzere vücut ağırlığı düzeyi (Sturm, 2002; Jia ve Lubetkin, 2005), uyku düzeni (Alvarez ve Ayas, 2004; Luyster vd., 2012), stres (Thoits, 2010) gibi unsurlar gelmektedir.

Literatürdeki farklı çalışmalar ise olumlu duyguların, çevre koşullarının, sosyoekonomik düzeyin sağlikla olan ilişkisine dikkat çekmiş̧tir (James vd., 1997; Strauss ve Thomas, 1998; Adler ve Ostrove, 1999; Akın, 2014). Veenhoven (2008) tarafindan yapilan araştırmada, "mutluluk, hastalıkları iyileştirmez ama hastalanmaya karşı korur" sonucuna varılmıştır. Bu bulgular, bir yandan da fiziksel sağlığı etkileyen pek çok unsurun, ruhsal sağlik üzerinde de etkili olduğuna işaret etmektedir. Örneğin fiziksel aktivite, beslenme, sosyo-ekonomik düzey ile biyolojik ve çevresel faktörler gibi pek çok faktör, ruhsal sağlık üzerinde de etkilidir.

Dünya Sağlık Örgütü ruhsal sağlığı, “sağlı̆̆ın ayrılmaz ve temel bir bileşeni”” olarak açıklamaktadır ve ruh sağlığı olmadığı zaman gerçek bir sağlıklılık halinden bahsetmenin 
mümkün olmadığı düşünülmektedir. Buna göre ruh sağlığı, "ruhsal bozuklukların veya engellerin yokluğundan çok daha fazlasıdır" (WHO, 2020b). Galderisi ve arkadaşlarının önerdikleri kapsamlı tanımdan da görülebileceği gibi ruhsal sağlık, "bireylerin yeteneklerini toplumun evrensel değerleriyle uyum içinde kullanmalarını sağlayan dinamik bir iç denge durumudur". Buna ek olarak aynı tanıma göre ruhsal sağlığı, "temel bilişsel ve sosyal beceriler, başkalarıyla empati kurmanın yanı sıra kendi duygularını tanıma ve ifade etme ile değiştirme yeteneği, olumsuz yaşam olaylarıyla başa çıkma esnekliği ve yeteneği, sosyal rollerde işlevsellik, beden ve zihin arasındaki uyumlu ilişki" gibi bileşenleri de temsil etmektedir (Galderisi vd., 2015: 231-232). Dünya Sağlık Örgütü'nün (WHO, 2020b) tanıma göre ise ruh sağlı̆̆ 1 , "bir bireyin kendi yeteneklerini fark ettiği, yaşamın normal stresleriyle baş edebildiği, verimli çalışabildiği ve toplumuna katkıda bulunabildiği bir refah durumudur".

Son olarak, toplumsal unsurlara da işaret eden sosyal sağlık ise Tognetti'nin (2014: 6069) de açıkladığı gibi, sağlığın üç temel boyutundan biri olmasına rağmen pek çok kişi için fiziksel veya ruhsal sağlık kavramlarından daha az anlaşılır bir kavramdır. Sosyal sağlık, bireyin toplum içinde iletişim kurabilmesi ve ortak davranışlar sergileyebilmesidir ve sosyal açıdan sağlıklılık hali, aile, arkadaşlar gibi toplumu oluşturan kişi ya da gruplar ile işbirliği yapma ve toplum tarafından kabul edilme ile ilgilidir (Ulutürk, 2015: 50). Farklı bir ifadeyle sosyal sağlık, dahil olma, sağlıklı ilişkiler kurma, bir arada yaşayabilme, aidiyet gibi unsurlara işaret etmektedir. Keyes (1998) sosyal sağlı̆̆ın "sosyal entegrasyon, sosyal katkı, sosyal tutarlılık, sosyal gerçekleştirme ve sosyal kabul" olmak üzere beş boyutundan bahsetmektedir. Tüm bu boyutlar, toplumsal hayatın sürdürülmesini sağlayan ve bireylerin o hayatın parçası olmasını mümkün kılan unsurlar iken, bunların tam tersini temsil eden sosyal hayattan kopma, izolasyon, yalnızlaşma ya da dışlanma gibi durumlar ise hem sosyal sağlık hem de ruhsal sağlık üzerinde olumsuz etkiler yaratabilmektedir.

Tüm bu açıklamalar sonucunda sağlığın disiplinlerarası bir çalışma alanı olduğu ve sosyolojik, psikolojik, ekonomik, çevresel, siyasal, kültürel ve hatta antropolojik açıdan incelenmesi gereken bir disiplin olduğu sonucuna varılmaktadır. Bu doğrultuda çalışma kapsamında kültürün ve kültürel farklılıkların sağlıklı olmaya ilişkin kodlar, algılar ya da kabuller üzerindeki etkisini anlamak ve kültürlerin değişimi, dönüşümü ve birbirleriyle olan ilişkisi bağlamında bu durumun sağlık üzerindeki etkilerinin izlerini sürmek gereklidir. Öte yandan "sağlıklı birey" algısına ilişkin kodların yaratımında ve kültürel farklılıkların veya benzeşmelerin üzerinde etkili unsurlardan birinin de popüler medya araçları olduğunu söylemek mümkündür. Kültür, sağlı̆̆ın boyutları ve medya araçları arasındaki ilişkinin nasıl işlediğini anlamak önemlidir.

\section{Sağlık ve Kültür İlişkisi}

Sağlıklı bireye ve bedene ilişkin yargılar, kültürel farklılıklara ve toplumsal gerçekliklere göre değişebilen bir olgudur. Okay'ın (2014: 1) vurguladığı gibi toplumlara ve kültürlere göre farklılık gösterebilen sağlıklı olma hali, ülkelerin değerleriyle yakından ilgilidir. $\mathrm{Bu}$ doğrultuda sağlıklı bireyin özellikleri, toplumsal ve kültürel bağlamda değerlendirilmesi gereken bir olgudur. Belirtildiği gibi, ruh sağlığına ilişkin tanımlar "onu tanımlayan kültürden açıkça etkilenirken" (Galderisi vd., 2015: 231), sağlık kapsamında yapılacak tanımlarda "kültürler arası farklılıklar akılda tutulmalıdır" (Vaillant, 2012). 
Kültür, çok tartışılan ve pek çok farklı tanıma sahip bir kavram olmakla birlikte bu çalışma kapsamında, "bireylerin, belirli bir toplumun üyeleri olarak miras aldıkları ve onlara dünyaya nasıl bakacaklarını, duygusal olarak nasıl deneyimleyeceklerini ve diğer insanlarla ilişki içinde nasıl davranacaklarını anlatan bir dizi kılavuz" (Helman, 2007: 2) olarak kabul edilmiştir.

Sağlık, hastalık ve hatta engelliliğin anlamları kültürlere ve zamana göre büyük ölçüde değişirken kültür, bunları nasıl algıladığımızı, deneyimlediğimizi ve yönettiğimizi de belirler (Ravindran ve Myers, 2012). Literatürde sağlığın kültürel boyutlarına işaret eden "tıbbi antropoloji”" çalışmalarına sıkça rastlanmaktadır. Helman'a (2007) göre tıbbi antropoloji, farklı kültürlerdeki insanların sağlık durumlarını açıklayan nedenleri, tedavi yöntemlerini, hastalık karşısında sergiledikleri davranışları vb. inceleyen çalışmalar olup aynı zamanda, sağlık ve hastalığın insan organizmasındaki biyolojik, psikolojik ve sosyal değişikliklerle nasıl ilişkili olduğunu anlamayı amaçlamaktadır. Bunun yanı sıra sağlık, kültür ve toplum arasındaki ilişki, sağlık sosyolojisi açısından da ele alınmakta ve tartışılmaktadır. Özen'in (1993: 74) tanımlamasıyla "sağlık sosyolojisi”, sağlık ile hastalık kavramlarını "toplumsal ve kültürel yapı içine yerleştirerek inceleyen" ve bunlar arasındaki nedensellik ilişkisini araştırıp anlamaya çalışan bir alandır.

Sağlık ve kültür arasındaki ilişki, pek çok farklı nokta üzerinden incelenebilir. Buna göre ilk olarak, sağlık ve hastalığa ilişkin anlamlandırma pratiklerinin kültürlere göre değişebildiği söylenebilir. İfade edildiği gibi “kültür, insanın sağlık algısını etkilemektedir" (Bolsoy ve Sevil, 2006). Sağlık algıS1, kültürel kabullerle de bağlantılı olarak bireyin sağlığa ilişkin öznel değerlendirmelerini içerir. Buna göre "bireylerin sağlık durumları hakkındaki inançlarının kendi kişisel durumları, içinde yaşadıkları toplum, ve kültürleri ile nasıl ilişkili olduğunu anlamak" (MacLachlan, 2006: 30) önemlidir.

Cirhinlioğlu'nun (2012: 39) Evans-Pritchard'ın 1937 yılında yapmış olduğu çalışmasından aktardığı gibi, Sudan'da cadıların, hastalıkların sebebi olduğu ve bu cadıların, hasta olan kişiyi sevmeyen komşuları tarafından harekete geçirildiğine inanıldığı görülmüştür. Literatürde çeşitli çalışmalarda da kültürel farklılıklar nedeniyle hastalıklara farklı anlamlar atfedildiği ve hastalık, doğa üstü olaylar, kötü enerji, cezalandırılma veya ilahi güç arasındaki ilişkiye dikkat çekildiği (Landrine ve Klonoff, 1994; Kopelman, 2002; MacLachlan, 2006) görülürken, Ulrich Beck'in (2002: 40) belirttiği gibi “modern öncesi tehlikeler, doğaya, Tanrılara ve şeytanlara atfedilmektedir".

Sağlık ve kültür arasındaki ilişki, tedavi yöntemleri üzerinden de okunabilir (MacLachlan, 2006). Kültürün etkisi, hastalıkların tedavisine ilişkin farklı yöntemler sunan "halk tıbbı" ya da "yerel tıp" olarak da adlandırılan bilgiler bütününde de karşımıza çıkmaktadır. Halk tıbbı, ait olduğu kültürün bir parçasıdır ve tedavi yöntemlerine ilişkin geleneksel bilgilerin çoğu, toplumsal tecrübe yoluyla oluşturulmuş ve nesilden nesile aktarılarak biriktirilmiştir(Kaplan, 2011: 151). Örneğin romatizmal hastalıkların tedavisine yönelik yapılan bir çalışmanın sonuçlarına göre, hastaların tamamlayıcı ve alternatif tıp yöntemlerine başvurma sıklığ 1 ve tedavi yöntemleri, kültürlere göre farkl1laşabilmektedir (Solak, ve diğerleri, 2015). 
Bunların yanı sıra yaşam tarzları ve kültürel değerler değiştikçe, sağlıklı olmanın nasıl bir beden yapısına ve hayat tarzına işaret ettiği de tartışılan bir konu haline gelmiştir. Fiziksel, sosyal ve psikolojik sağlıklılık hali, zaman içinde meydana gelen toplumsal değişimlerden de etkilenerek dönüşebilmektedir. Örneğin temel ihtiyaçlardan biri olan beslenme alışkanlıkları bile, kültürel ve toplumsal bir konu olarak karşımıza çıkabilmektedir. Yaşam tarzının da bir yansıması olarak görülebilecek yiyecekler ve beslenme alışkanlıkları, Helman'ın vurguladığı gibi, besin kaynağından çok daha fazlası olarak ele alınmaktadır. Buna göre beslenme alışkanlıkları günlük yaşamın sosyal, dini ve ekonomik yönlerine derinlemesine yerleşmiştir ve toplumsal açıdan pek çok sembolik anlam taşımaktadır. "Ne yediğin ya da ne yemeği reddettiğin" bile, kültürel ve toplumsal anlamlar içermektedir (Helman, 2007: 52).

Bazı toplumlarda ve kültürlerde sağlıklılık hali genellikle, fiziksel yetkinlikler, bedenin somut göstergeleri, hastalık ya da hastalığın olmaması üzerinden açıklanmaktadır. Öncel'in (1997: 182) aktardığ 1 gibi kimi toplumlarda bireyin kendi gündelik hayatını idame ettirmesi ve işini görüp ihtiyaçlarını karşılayabilmesi sağlıklı sayılma ölçütlerindendir. Ancak sağlığa atfedilen bu anlam sağlığı, yalnızca fiziksel kapasite üzerinden açıklamaktadır. Sağlığı fiziksel özelliklere indirgeyen yaklaşımların bir kısmı da sağlığı sadece sakatlığın olmayışı, fiziksel kapasite ve işlevsellik üzerinden değil, aynı zamanda da bedenin dışarıdan görünen somut özellikleri üzerinden de açıklama eğilimine sahiptir ve bu eğilimin oldukça yaygın olduğu varsayılmaktadır. Örneğin zayıf olmak bir bedene sahip olmak, kimilerine göre bir sağlık göstergesi gibi okunabilir ancak zayıf olmanın tek başına sağlıklı olma haline işaret ettiğini söylemek mümkün değildir. Sağlıklı bedenin bahsedilen somut göstergeleri ise, kültürel ve toplumsal kabullerden doğrudan etkilenmektedir.

Öte yandan özellikle fiziksel sağlığın, sosyal ve ruhsal sağlığa göre çok daha somut göstergeleri olması, sağlığ değerlendirilebilir. MacLachlan'ın (2004: 15-17) açıklamasıyla kültürel faktörler, vücut şekillendirme üzerinde güçlü bir etkiye sahipken beden, yalnızca fiziksel bir gerçeklik değil aynı zamanda kültürel inançlarla şekillenen de bir unsurdur ve hemen hemen her kültürde, vücudu dekore etmenin veya güzelleştirmenin farklı yolları bulunmaktadır.

Sonuç olarak kültürel farklılıkların; sağlığın tanımı, tedavi yöntemleri, sağlığa atfedilen anlam, bedenin deneyimlerine bakış açısı, yeme-içme pratikleri, bedenin görüntüsü gibi pek çok alan üzerinde etkili olduğunu söylemek mümkündür. Kültürel bir perspektiften bakıldığında, sağlık veya hastalık algısını etkileyen pek çok faktör bulunmaktadır. Bunların başında, "ekonomik durum, aile yapısı, cinsiyet rolleri, cinsel davranış biçimleri, genel sağlık düzenlemeleri, nüfus politikaları" vb. unsurlar gelmekle birlikte "vücut imajındaki değişimler, beslenme, giyinme, meslekler, kişisel hijyen, alışkanlıklar" (Bolsoy ve Sevil, 2006: 82-85) gibi daha pek çok unsur da sağlık algısını etkileyebilmektedir. 


\section{Küreselleşme ve Medya Ekseninde Sağlık Mitleri}

Küreselleşme çok boyutlu ve disiplinlerarası bir kavram olup, küreselleşme ekseninde yürütülen tartışmalar oldukça kapsamlı bir literatüre dayanmaktadır. Ancak çalışmanın kapsamının çok ötesinde olan bu tartışmalar, ekonomik, sosyal, politik, kültürel, ticari, iletişimsel vb. pek çok perspektiften yürütülebilir. Kapsamı gereği bu çalışmada küreselleşme kavramı Giddens ve Sutton'un tanımından yola çıkılarak ele alınmaktadır. Yazarlara göre küreselleşme "coğrafi olarak dağılmış insan nüfusunun, dünyayı tek bir topluluğa ya da küresel bir topluma doğru evrimleştiren çeşitli süreçler aracılığıyla, daha yakın hale gelmesi ve birbirleriyle daha hızlı etkileşimlere girebilmesi durumu" (Giddens ve Sutton, 2018: 21) olarak açıklanabilir. Bu doğrultuda küreselleşmenin ve bununla bağlantılı olarak medyanın etkisiyle insanların, toplumların ve kültürlerin benzeşmesine ve yakın hale gelmesine ilişkin tartışmalar, günümüzde de süregelen tartışma konularındandır.

Küreselleşmenin insanların yaşam tarzlarına, düşünme biçimlerine, günlük hayatlarına, değerlerine ve kültürlerine vb. olan etkileri, çeşitli disiplinler ve çalışma alanları üzerinden incelenebilirken, bu alanlardan biri de sağlıktır. Küreselleşmenin, sağlık ve sağlık sistemi üzerine olumlu ve olumsuz olmak üzere pek çok farklı etkisinden bahsedebilmek mümkün olmakla birlikte, medyanın ve popüler kültür ürünlerinin sağlığın tanımı ve sağlık algısı üzerindeki etkilerini yadsımamak gerekmektedir. Son yıllarda öne çıkan sağlığa ilişkin çeşitli göstergeler, medyanın da aracılığıyla giderek daha fazla kabul görür hale gelmiştir. MacLachlan'ın (2004: 99) belirttiği gibi popüler kültür, hem erkek hem de kadın bedeninin görünümü üzerinde oldukça etkilidir. Özellikle küresel ölçekte yayınlanan ve dağıtımı yapılan sağlık, fitness, moda dergileri gibi popüler medya ürünlerinin, bu yayılımın hızı üzerinde de etkisi olduğunu söylemek mümkündür. Aynı zamanda bu yayınlar, kültürel farklılıkların silikleşmesine yol açarken, küresel bir sağlık, beden ve iyilik algısı yaratma işlevine de sahiplerdir.

Daha önce de ifade edildiği gibi, sağlığın fiziksel görünüş üzerinden tanımlanması eğilimini arttıran unsurlardan biri de medya araçları olabilir. Buna ek olarak, söz konusu bedenin görünüşü olduğunda, kadınların genellikle daha ön planda olduğu kabul edilmektedir. MacLachlan'ın vurguladığı gibi, tüm kültürlerde kadın ve erkekler için farklı roller ve beklentiler bulunurken, bunlar aynı zamanda sağlıkla da ilgilidir. Ancak bu noktada kadınların daha dezavantajlı konumda olduğunu söylemek mümkündür (MacLachlan, 2006: 24). Örneğin, Aubrey (2010) tarafından kadın sağlığı dergilerinin kapaklarında yer alan sağlı tavsiyelerinin nasıl çerçevelendiğinin analiz edilmesini amaçlayan çalışmada, "görünüm" çerçevelerinin, sağlık çerçeveleri kadar yaygın olduğu sonucuna erişilmiştir.

Sağlığı beden üzerinden tanımlama eğilimi, bedenin taşıdığı anlamlar ile de ilişkilidir. Helman'ın (2007: 19) açıkladığı gibi beden, “toplumdaki bireyler için sağlık ve hastalık arasında gidip gelen fiziksel bir organizmadan daha fazlasıdır" ve "her toplumda, insan vücudunun fiziksel olduğu kadar sosyal bir gerçekliği de vardır”. Bedenin, kültür, toplum ve sağlık açısından önemi, sağlığa ilişkin pek çok temsili mitin de gündeme gelmesine yol açmaktadır. Lesser ve arkadaşları, beslenme ile ilgili bilimsel kanıtlarla yeterince desteklenmeyen veya çelişen bilgiler sunan diyet mitlerinin, kimi durumlarda 
sağlıklı beslenme açısından sorun yaratabildiğini ifade etmiştir. Örneğin, yağın obeziteye yol açtığı ve damar sağlığına zararlı olduğu, tüm liflerin yararlı olduğu, gıda kalorisi ile vücut ağırlığı arasında doğrudan ilişki olduğu gibi söylemler indirgemeci bir yaklaşımdır ancak beslenme, bütüncül bir bakış açısıyla ele alınmalıdır (Lesser vd., 2015).

Medyada ve özellikle de internette, sağlığa ilişkin bazı beslenme önerilerinin tehlikeli olabileceğine dikkat çeken bir çalışmaya göre, sağlıksız ve yan etkilere yol açabilen diyetler veya ünlüler tarafından kullanılan ancak sağlıklı olduğu kanıtlanmamış ürünlere ilişkin bilgiler gittikçe yayılmakta ve insanlar, potansiyel olarak zararlı olabilecek sağlık mitlerine inanma eğilimindedirler (Collier, 2018).

Özellikle son y1llarda oldukça ön planda olan sağlık ve diyet ilişkisi, bir yandan sağlığı beden ve vücut şekli üzerinden açıklamanın somut bir göstergesi olarak okunabilirken, bir yandan da doğru ya da yanlış pek çok karmaşık bilginin dolaşıma girdiği bir alan olarak karşımıza çıkmaktadır. Amerika'da 2009 yılında yayınlanan bir çalışma kilo verme ve beslenmeye ilişkin pek çok kabul görmüş mite dikkat çekmektedir. Örneğin, yüksek protein ve düşük karbonhidratlı diyetin kilo vermek için sağlıklı olduğu, nişastanın şişmanlattığı, yağ yakmaya yardımcı yiyecekler olduğu ve bunlarla beslenmenin kilo vermeye neden olacağ 1 , doğal ve bitkisel zayıflama ürünlerinin güvenli olduğu, kilo vermek için ögün atlamak gerektiği, akşam sekizden sonra yemek yemenin kilo aldırdığ1, kırmızı etin ve kuruyemişin sağlıksız olduğu ve kilo aldırdığı, süt ürünlerinin sağlıksız olduğu (U.S. Department of Health and Human Services, 2009) gibi bir çok düşünce, medyanın da aracılığıyla kabul görmüş gerçekler gibi kamuoyuna sunulmaktadır. Bu açıdan bakıldığında son yıllarda daha "fit" ya da zayıf bir görünümün, sağlık açısından önemli bir gösterge olduğu sonucuna varmak mümkündür. Kadın sağlığı-fitness ile güzellik-moda dergilerindeki dergi kapakları analiz eden bir çalışmanın sonuçları, sağlıkfitness dergilerindeki modellerin dikkat çekici derecede zayıf olduğunu ortaya koymuştur ve aynı zamanda her iki dergi türünde de, sağlıtan ziyade görünümle ilgili olarak içeriklerin daha çok yer aldığı saptanmıştır (Conlin ve Bissell, 2014). Bu açıklamalardan da anlaşılacağı gibi, günümüzde küresel medya yayınlarında sağlığın kapsamı daha çok görünüm ve beden ile vücut yapısı üzerinden açıklanırken, bedene ve sağlığa ilişkin mitlere dayanan bu algı ve kabullerin, küresel düzeyde yayıldığı görülmektedir.

Diyet ve beslenmeye ilişkin popüler algılar, beslenme ile sorunların da küreselleşmesi olarak gözlemlenmektedir. MacLachlan'ın (2004: 99) ifade ettiği gibi, "bir zamanlar kültüre bağlı bir hastalık olarak kabul edilen anoreksiya nervoza son yıllarda Batılı olmayan birçok ülkede de görülmektedir" ve bu durum doğrudan küreselleşme ekseninde açıklanabilir. Öte yandan bedene ilişkin sağlık göstergelerinin Batı kültürü egemen yapısı ise özellikle dikkat çekicidir (Helman, 2007). Tüm bunların sonucunda sağlığa ilişkin kültürel kabullerin giderek silikleşerek küresel bir sağlıklı beden algısının, medyanın da yardımıyla giderek daha fazla kabul gördüğünü söylemek mümkündür.

\section{Yöntem}

Amerika ve Türkiye'de 2009 ve 2019 yılları arasında yayınlanan Women's Health dergi kapaklarının, sağlığın boyutları ve haber başlıklarının analiz edildiği bu 
çalışmanın örneklemini 231 dergi kapağı oluşturmaktadır. Okuyucuları dergiye çeken ilk unsurun dergilerin kapaklarının olması ve kapağın genellikle içerikte bulunan pek çok haber başlı̆̆ını içermesi (Malkin vd., 1999; Aubrey, 2010) nedeniyle bu çalışma, dergi kapaklarının incelenmesi ile sınırlandırılmıştır.

Çalışma, “2009-2019 yılları arasında Amerika ve Türkiye'de yayınlanan Women’s Health dergi kapaklarında yer alan fiziksel, ruhsal ve sosyal sağlık kategorilerinin dağılımı nasıldır? "Sağlı̆̆ın üç ana kategorisinin alt kategorilerine ilişkin başlıkların dağılımları nasıldır ve iki ülke arasında benzerlik ya da farklılık var mıdır?", "Dergi kapaklarında bulunan kapak kızlarının uyrukları ve bunların dağılımı nasıldır ve iki ülkenin kapak kızlarına ilişkin dikkat çeken unsurlar nelerdir?” sorularına cevaplar aranmaktadır. Bu doğrultuda çalışmada, sosyal bilimler ve iletişim alanında sık kullanılan yöntemlerinden biri olan içerik analizi yönteminden faydalanılmıştır. İçerik analizi araştırmacılara, insan davranışı üzerine doğrudan olmayan yollarla çalışmaya olanak sunmaktadır (Büyüköztürk vd., 2016: 250). Aynı zamanda içerik analizi, yazılı veya sözel metinlerden sistematik olarak verileri analiz edilebilmesini de sağlamaktadır (Skalski vd., 2017).

Çalışmada analizin gerçekleştirilmesi için kodlama şeması oluşturulmuş ve örneklemin yüzde 10'luk bir kısmı araştırmacılar tarafından bu şemaya göre kodlanarak, şemada dikkat çeken eksiklikler giderilerek son hali verilmiştir. Son olarak elde edilen kodlama şeması doğrultusunda analizler gerçekleştirilmiştir. Kodlama şemasında sekiz ana kategori ve çeşitli alt kategoriler bulunmaktadır (Tablo 1).

Tablo 1'de yer alan kodlama kategorileri doğrultusunda kodlamalar, SPSS 20.0 paket programı kullanarak gerçekleştirilmiştir. İnceleme kapsamına alınan 2009 ile

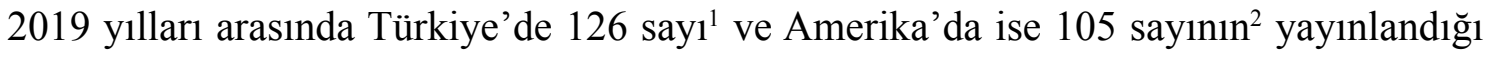
görülmüştür ve tüm sayılar araştırmaya dahil edilmiş̧tir. Araştırmada elde edilen veriler, frekans ve çapraz tabloları ile sunulmuştur.

Tablo 1. İçerik analizi kodlama kategorileri

\begin{tabular}{|l|l|}
\hline Ana kategori & Alt kategoriler \\
\hline Ülke & $\begin{array}{l}\text { Türkiye } \\
\text { Amerika Birleşik Devletleri }\end{array}$ \\
\hline \multirow{2}{*}{ Ylllar } & $\begin{array}{l}2009-2010-2011-2012-2013-2014-2015-2016-2017-2018- \\
2019\end{array}$ \\
\hline \multirow{2}{*}{ Aylar } & $\begin{array}{l}\text { Ocak- Subat- Mart- Nisan- Mayıs- Haziran- Temmuz- } \\
\text { Ağustos- Eylül- Ekim- Kasım- Aralık }\end{array}$ \\
\hline \multirow{3}{*}{ Kapak kızının uyruğu } & $\begin{array}{l}\text { Türkiye- Amerika Birleşik Devletleri- İtalya- Kanada- } \\
\text { İngiltere- Rusya- İspanya- Yunanistan- Almanya- } \\
\text { Kolombiya- Avustralya- Sirbistan- Portekiz- Şili- Hindistan }\end{array}$ \\
\hline
\end{tabular}

1 Derginin 2019 Haziran ayı sayısı, Türkiye'de yayınlanan son sayısı olmuştur. Bu nedenle çalışmada 126 dergi Türkiye örneklemi için araştırma kapsamına alınmıştır.

2 Derginin Amerika'da yayınlanan versiyonlarında Ocak-Şubat ve Temmuz-Ağustos sayılarının birlikte yayınlandığı görülmüştür. 


\begin{tabular}{|l|l|}
\hline \multirow{3}{*}{ Sağlı̆̆ın boyutları } & Ruhsal \\
& Sosyal \\
& Fiziksel \\
\hline \multirow{3}{*}{ Sosyal sağlık alt kategoriler } & Profesyonel yaşam \\
& Arkadaş ve aile ilişkileri \\
& Duygusal ilisskiler \\
\hline \multirow{5}{*}{ Fiziksel sağlık alt kategoriler } & Diyet - beslenme \\
& Güzellik \\
& Kilo verme \\
& Spor - egzersiz \\
& Genel sağlık \\
& Dış görünüş \\
\hline
\end{tabular}

Araştırmada kodlayıcılar arası güvenilirlik sağlanmasına da önem verilmiştir. İçerik analizinde kodlayıcılar arası tutarlılık oldukça önemli bir konudur. Tutarlılığ sağlamak için kodlayıcılar aynı metni bağımsız olarak kodlamakta ve ardından tutarlılık kontrol edilmektedir. Bu amaçla kodlayıcılar arası güvenilirlik, istatistiksel bir katsayı ile ölçülmektedir (Neuman, 2014). Krippendorff (2013: 267) güvenilirliğin, bir araştırmada aynı fenomene aynı şekilde yanıt verildiğinde gerçekleştiğini ifade etmektedir.

Literatürden hareketle oluşturulmuş ve düzenlemeleri yapılmış kodlama kategorileri doğrultusunda 2009-2019 yılları arasında Amerika ve Türkiye'de yayınlanan Women's Health dergilerinin kapaklarında yer alan içerikler, iki araştırmacı tarafından ayrı ayrı kodlanmış $(n=1578)$ ve çalışmanın güvenilirliği için Scott's pi $(\pi=\mathrm{Po}-\mathrm{Pe} / 1-\mathrm{Pe})$ hesaplanmıştır (Krippendorff, 2013: 303). Po iki kodlayıcı arasında gözlemlenen anlaşma oranı, Pe ise iki kodlayıcı arasında beklenen uzlaşma oranını temsil etmektedir. Yapılan hesaplama sonrasında kodlayıcılar arası güvenilirlik 0,83 olarak bulunmuştur. Kodlayıcılar aras1 güvenirliğin ölçümü \% 70 üzerinde olduğu için güvenirlik oranı konusunda bir sorun olmadığı görülmüştür (Tavşancıl ve Aslan, 2001).

\section{Bulgular}

Türkiye'de ve Amerika'da 2009-2019 yılları arasında yayınlanan Women's Health dergilerinin incelendiği çalışmada öncelikle, fiziksel, ruhsal ve sosyal sağlik ile ilgili dergi kapaklarında yer alan başlıklar değerlendirilmiştir.

Yapılan inceleme sonucu her iki ülkede de en çok fiziksel sağlığa ilişkin konulara yer verildiği sonucuna ulaşılmıştır. Bu doğrultuda, 2009 ile 2019 yılları arasında Amerika'da toplamda 467, Türkiye'de ise 683 başlığın fiziksel sağlik ile ilgili olduğu bulunmuştur. Buna göre Türkiye'de sağlığın üç boyutundan biri olan fiziksel sağlık kapsamında Amerika'ya göre daha fazla başlığa yer verildiği görülmüştür (Tablo 2). 
Tablo 2. Women's Health Türkiye ve Amerika Dergilerinde yıllara göre fiziksel sağlık ile ilgili konuların dağılımı

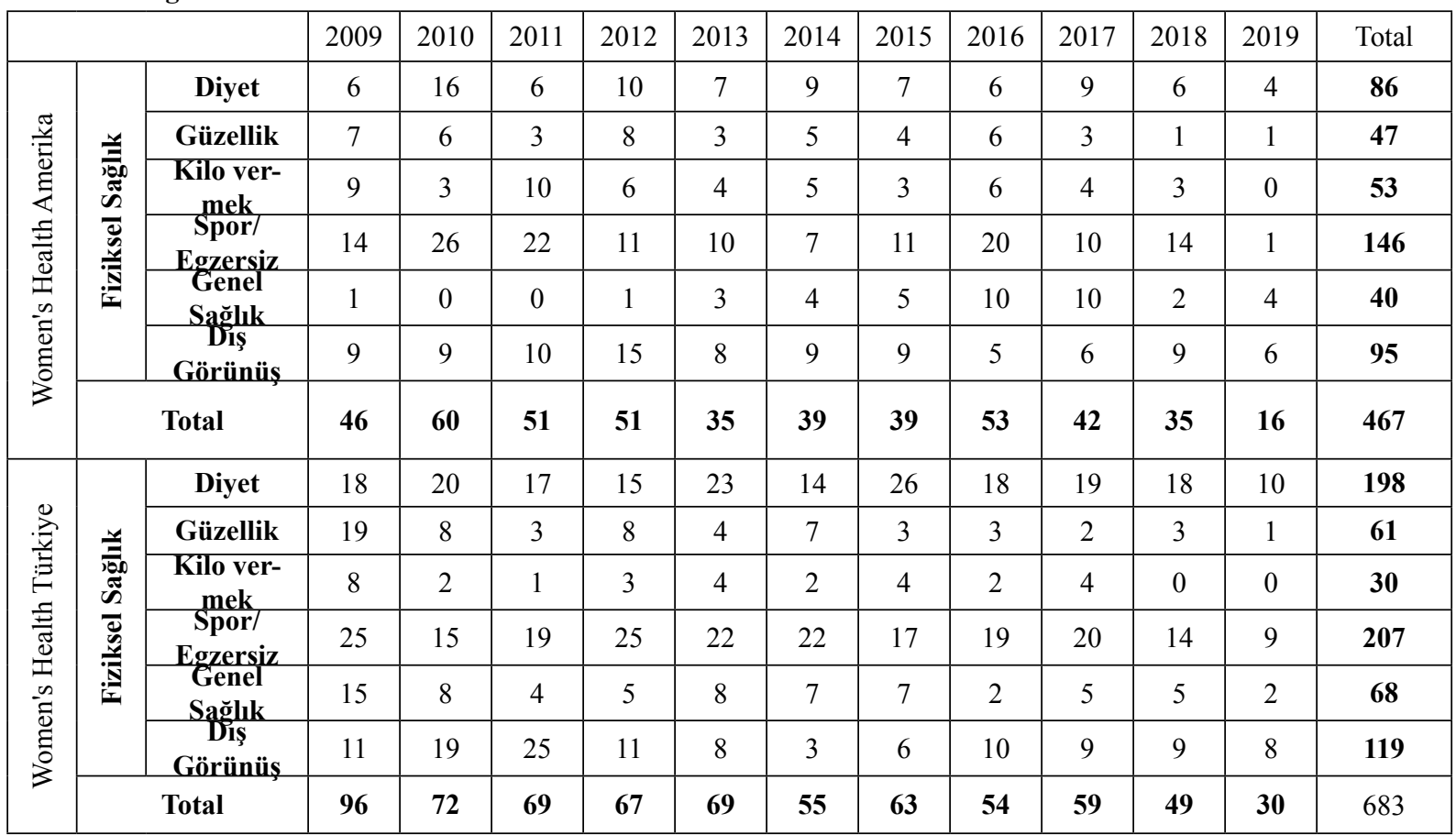

Fiziksel sağlığın alt kategorilerine göre yapılan incelemede ise, Amerika'da ilk üç sırada, "spor/egzersiz" ( $n=146)$, "dış görünüş" $(n=95)$ ve "diyet" $(n=86)$ ile ilgili konuların, Türkiye'de ise, "spor/egzersiz" (n=207), "diyet" (n=198) ve "dış görünüş" $(n=119)$ ile ilgili konuların ele alındığı saptanmıştır (Tablo 2).

Her iki ülkede yayınlanan dergilerin kapaklarında yer alan ruhsal sağlık ile ilgili başlıklar değerlendirildiğinde, Amerika'da 56, Türkiye'de ise 73 başlık olduğu görülmüştür. Buna göre dergilerde, fiziksel sağlıktan sonra ikinci olarak en çok ruhsal sağ lığa ilişkin konulara yer verildiği anlaşılmıştır. Yıllara göre dağglıma bakıldığında ise her iki ülkede de en çok 2017 ve 2018 yıllarında ruhsal sağllğa ilişkin başlıklara yer verildiği sonucuna erişilmiştir. Türkiye'de konuyla ilgili daha fazla başlığın olduğu da dikkat çekmiştir (Tablo 3).

Tablo 3. Women's Health Türkiye ve Amerika Dergilerinde yıllara göre ruhsal sağlık başlıklarının dağılımı

\begin{tabular}{|c|c|c|c|c|c|c|c|c|c|c|c|c|c|c|}
\hline & & & 2009 & 2010 & 2011 & 2012 & 2013 & 2014 & 2015 & 2016 & 2017 & 2018 & 2019 & Total \\
\hline 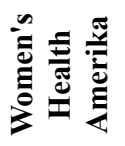 & 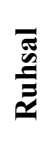 & 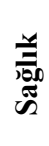 & 5 & 1 & 5 & 5 & 1 & 2 & 3 & 7 & 9 & 11 & 7 & 56 \\
\hline 章 至 & 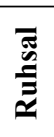 & 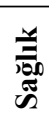 & 9 & 6 & 3 & 4 & 2 & 3 & 4 & 5 & 13 & 19 & 5 & 73 \\
\hline
\end{tabular}


Fiziksel ve ruhsal sağlığın yanı sıra, sağlığın bir diğer boyutu olan sosyal sağlık açısından dergiler incelendiğinde her iki ülkede de eşit sayıda konu başlığı olduğu saptanmıştır. Buna göre, 2009 ile 2019 arasında hem Amerika'da hem de Türkiye'de sosyal sağlık ile ilgili toplam 19 başlığa yer verilmiştir. 2011 yılında her iki ülkede de bir sene boyunca sosyal sağlığa ilişkin hiçbir içeriğin dergide yer almadığı görülmüş, 2014 y1lında Türkiye'de, 2019 yılında ise Amerika' da konuyla ilgili herhangi bir konunun ele alınmadığı görülmüştür.

Profesyonel yaşam, arkadaş-aile ilişkileri ile duygusal ilişkiler alt kategorileri altında sosyal sağlıkla ilgili başlıklar incelendiğinde ise, Amerika'da en çok duygusal ilişkiler hakkında, Türkiye' de ise en çok iş profesyonel yaşam hakkında içeriklere yer verildiği sonucuna varılmıştır. Her iki ülkede de en az arkadaş ve aile ilişkilerine dair içeriklere yer verilmiştir (Tablo 4).

Tablo 4. Women's Health Türkiye ve Amerika Dergilerinde yıllara göre sosyal sağlık ile ilgili konuların dağılımı

\begin{tabular}{|c|c|c|c|c|c|c|c|c|c|c|c|c|c|c|}
\hline & & & 2009 & 2010 & 2011 & 2012 & 2013 & 2014 & 2015 & 2016 & 2017 & 2018 & 2019 & Total \\
\hline \multirow{4}{*}{ 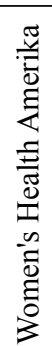 } & \multirow{3}{*}{ 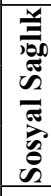 } & $\begin{array}{c}\text { Duygusal } \\
\text { iliskiler }\end{array}$ & 3 & 1 & - & 1 & - & - & 1 & - & 2 & 1 & - & 9 \\
\hline & & Profesyonel & - & - & - & 2 & 1 & 1 & 1 & 1 & 1 & - & - & 7 \\
\hline & & $\begin{array}{l}\text { Arkadaş- } \\
\text { Aile }\end{array}$ & - & - & - & - & 1 & - & - & 2 & - & - & - & 3 \\
\hline & & Total & 3 & 1 & - & 3 & 2 & 1 & 2 & 3 & 3 & 1 & - & 19 \\
\hline \multirow{4}{*}{ 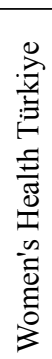 } & \multirow{3}{*}{ 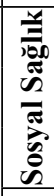 } & $\begin{array}{c}\text { Duygusal } \\
\text { Iliskiler }\end{array}$ & 2 & - & - & - & - & - & 1 & 0 & 1 & 1 & 2 & 7 \\
\hline & & $\begin{array}{c}\text { Profesyone } \\
\text { vasam }\end{array}$ & 0 & - & - & 2 & 1 & - & 1 & 2 & - & 3 & 0 & 9 \\
\hline & & $\begin{array}{c}\text { Arkadaş- } \\
\text { Aile }\end{array}$ & 1 & - & - & 1 & - & - & - & - & - & - & 1 & 3 \\
\hline & & Tota & 3 & 2 & - & 3 & 1 & - & 2 & 2 & 1 & 4 & 3 & 19 \\
\hline
\end{tabular}

Çalışmanın literatür kısmında da detaylı bir biçimde açıklandığı gibi, sağlık disiplinlerarası bir çalışma alanı olmasının yanı sıra kültürel bir olgu olarak da karşımıza çıkmaktadır. Dergilerde yer alan görsellerin de, kültürel açıdan önemli olduğu düşünülmektedir. Bu doğrultuda incelenen dergilerde yer alan kapak kılarını, kültürel bir unsur olarak değerlendirmek mümkündür ve çalışmada bu açıdan da bir analiz gerçekleştirilmiştir.

Amerika ve Türkiye'de yayınlanan Women's Health dergisine kapak olan kişilerin uyruklarına ilişkin yapılan analizde genellikle Amerikalılara yer verildiği saptanmıştır. Amerika'da yayınlanan dergi kapaklarında yer alan kişilerin uyruklarına ilişsin yapılan analizde ilk üçte sırasıyla Amerika $(\% 76,9, \mathrm{n}=80)$, Kanada $(\% 6,6$, $\mathrm{n}=7)$ ve İngiltere $(\% 4,8, \mathrm{n}=5)$ yer almaktadır. İncelenen dergilerde az sayıda da 
olsa farklı ülkeleri temsilen kapak kızları olmakla birlikte Amerikalıların niceliksel olarak çokluğu, derginin menşeini de açıç̧a ortaya koymaktadır. Ancak bu ülkelerin arasında Türkiye'nin yer almaması ayrıca dikkat çekicidir (Grafik 1) dağılım

Grafik 1. Amerika'da Yayınlanan Women's Health Dergisindeki kapak kızlarının uyruklarına ilișkin

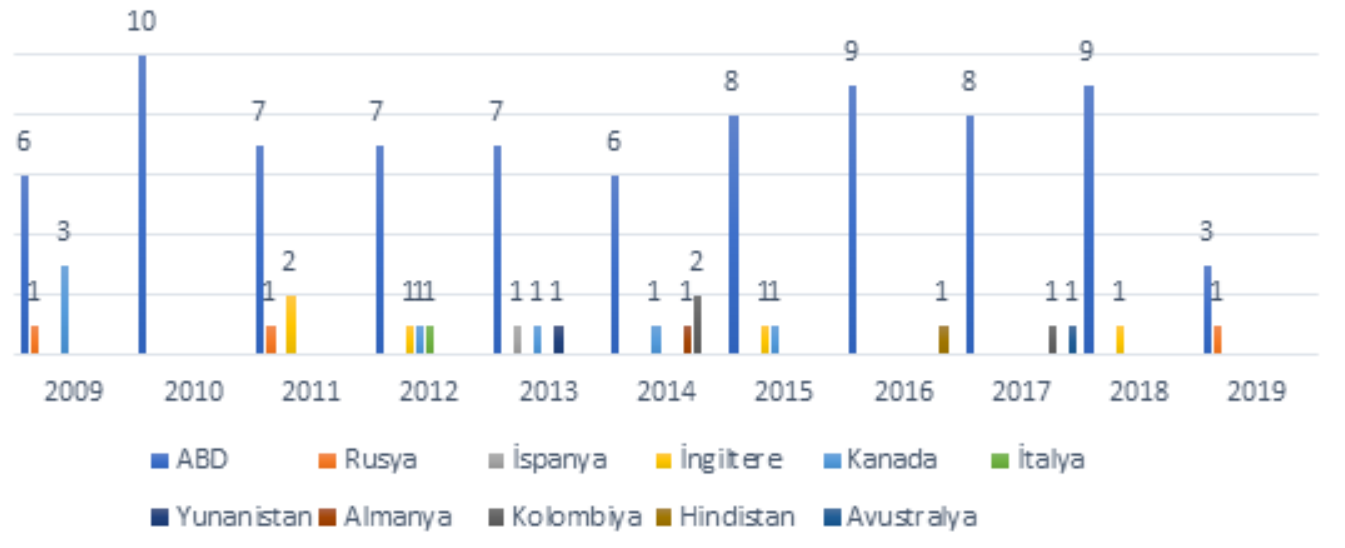

Türkiye'de yayınlanan dergilerde ise Türk kapak kızlarına da yer verildiği görülmüş ve yapılan incelemede Amerikalı ve Türk kapak kızlarının eşit sayıda (n=47) olduğu anlaşılmıştır. 2009 ile 2019 yılları arasında Türkiye' de yayınlanan dergilerde ise sırasıyla en çok, Türk ve Amerikalı $(\% 39,8, \mathrm{n}=47)$ ile Kanadalı $(\% 4,5, \mathrm{n}=5)$ kapak kızlarına yer verilmiştir. Türkiye'de yayınlanan dergilerde Türk kapak kızlarının da kullanılması, derginin yayınlandığı ülkedeki yerel değerlere de önem verdiğini ve dikkat ettiğinin göstergesi olarak değerlendirilebilir (Grafik 2).

Grafik 2. Türkiye'de Yayınlanan Women's Health Dergisindeki kapak kızlarının uyruklarına ilişkin dağılım

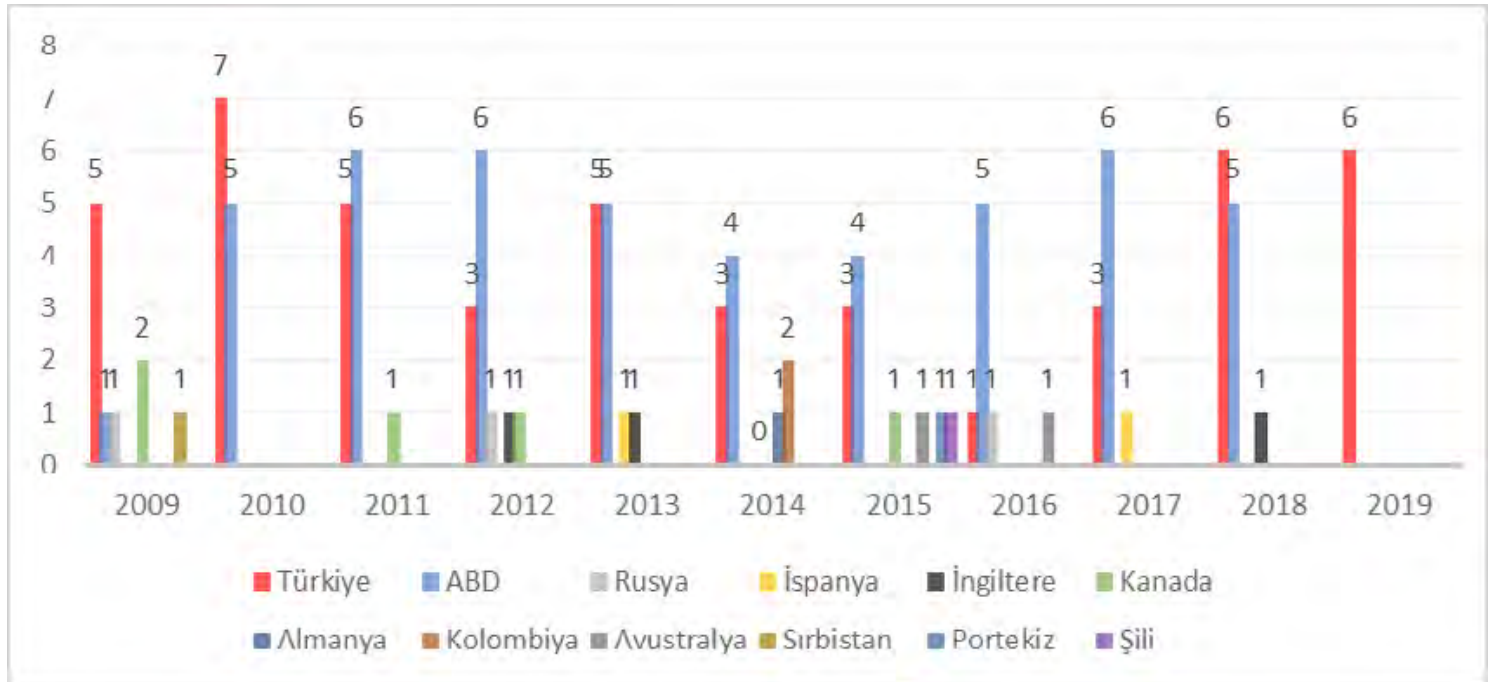




\section{Sonuç ve Tartışma}

Sağlık, "fiziksel, sosyal ve ruhsal" olmak üzere üç boyut etrafinda tanımlanmakla birlikte, 2009 ile 2019 yılları arasında Amerika ve Türkiye'de yayınlanan Women's Health dergi kapaklarında sağlığın daha çok fiziksel sağlık olarak ele alındığ 1 sonucuna erişilmiştir. Bu doğrultuda her iki ülkede de dergilerde en fazla fiziksel sağlık (Amerika $n=467$, Türkiye $n=683$ ) ile ilgili içeriklere yer verildiği anlaşılmıştır. En az sosyal sağlık hakkında içeriklere yer verilen dergilerde, ruhsal sağlık hakkındaki içeriklerin ise görece daha fazla olduğu dikkat çekmiştir. Elde edilen sonuçlar, Conlin ve Bissell'in yaptıkları çalışma sonuçları ile de örtüşmektedir. Yazarlar çalışmalarında dergilerde özellikle fiziksel görünüm ile ilgili içeriklerin daha fazla olduğu bulgulamışlardır (Conlin ve Bissell, 2014). Buna göre fiziksel sağlığın birincil göstergesinin, fiziksel görünüm ile ilişkilendirildiğini söylemek mümkündür. Araştırmanın bulguları da, bu sonucu destekler niteliktedir. Aynı zaman literatürde farklı çalışmalarda da benzer bulgulara erişildiği dikkat çekmiştir. Malkin ve arkadaşları (1999) ile Aubrey'in (2010) yapmış olduğu çalışmalar, dergilerde beden görünümü ile ilgili içeriklerin yoğunluğunu ortaya koymuştur.

Çalışma kapsamında incelenen dergi kapaklarında, Dünya Sağlık Örgütü tarafından sağ lığın boyutları olarak tanımlanan ruhsal ve sosyal sağlığa ilişkin, fiziksel sağlığa oranla çok daha az sayıda içerik paylaşıldığı görülmüş ve bu durumun her iki ülke için de geçerli olduğu anlaşıllmıştır. Amerika ve Türkiye' de de, ruhsal sağlıkla ilgili konuların (Amerika $n=56$, Türkiye $n=73$ ), fiziksel sağliktan (Amerika $n=467$, Türkiye $n=683$ ) sonra ikinci sırada ele alınan başlık olduğu anlaşılmıştır.

Sosyal sağlıkla ilgili başlıklar ise her ülkede de eşit sayıda (Amerika ve Türkiye n= 19) olmasına rağmen sağlı̆ın boyutları arasında kendine en az yer bulan konu olmuştur. Amerika'da yayınlanan dergilerde, sosyal sağlığın alt boyutları sırasıyla duygusal ilişkiler, profesyonel yaşam ve arkadaş/aile ilişkileri olarak görülürken Türkiye'de, profesyonel yaşam, duygusal ilişkiler ve arkadaş/aile ilişkileri sıralamasıyla görülmüştür. Hofstede'nin (2001) tanımladığı gibi Türkiye'nin, Amerika'nın aksine kolektif bir toplum olması, arkadaş/aile ile ilgili başlıkların daha çok olacağı beklentisini yaratırken, elde edilen bulgular bu beklentiyi desteklememiştir ve elde edilen bu sonuç küreselleşmenin bir etkisi olarak değerlendirilebilir. Buna göre küresel ve popüler yayınlar bir yandan küresel değerlerin yayılımı hızlandırırken, bir yandan da sahip oldukları içerikler ile küreselleşmenin etkilerinin görülebileceği mecralar olarak karşımıza çıkmaktadır. Bununla bağlantılı olarak dergilerde yer alan kapak kızlarının uyruklarına ilişkin analiz de küreselleşmenin etkilerini yansıtmaktadır.

İncelenen Women's Health dergisi, menşei Amerika Birleşik Devletleri olan ve pek çok ülkede yayınlanan bir dergidir. 2009 ile 2019 yılları arasında Amerika' da yayınlanan dergilerde hiç Türk kapak kızı olmaması, dikkat çekici bir sonuçtur. Amerika'da yayınlanan dergilerde farklı ülkelerin manken, model ya da oyuncularına yer verildiği ancak bu kişilerin de genellikle küresel ölçekte tanınmış kişiler olduğu görülmüştür. $\mathrm{Bu}$ doğrultuda popüler dergilerin küresel değerleri ve kabulleri yayması açısından işlevi daha net görülebilmektedir. Amerika' da hiç Türk kapak kızı kullanılmamakla birlikte, Türkiye örnekleminde yapılan incelemede Amerikalı ve Türk kapak kızlarının eşit sayıda olduğu saptanmıştır. Buna göre Türkiye'de kullanılan kapak kızlarının \%39,8'i Amerikalı, 
\%39,8'i ise Türk manken, model, sporcu ya da oyunculardan oluşmaktadır. Kapakların okuyucuların ilk gördükleri yer almasından ötürü, kapakta yer alan içerik başlıkları kadar görsellerin de önemli olduğu düşünülmektedir. Bu açıdan kapak kızlarının sahip oldukları özelliklerin ve fiziksel görünümlerin, küresel olarak kabul edilen, sağlıklı beden, fiziksel yapı ile güzellik gibi unsurları betimlediğini ve etkilediğini söylemek mümkündür. Sağlık, sağlıklı beden ve estetik görünme açısından kurgulanan bu algıların ise genelde merkezi bir anlayış çerçevesinde kurgulandığını ve yayıldığını varsaymak olasıdır. Alternatif sağlık ve sağlıklı beden temsillerinin görece daha dar çerçevede kabul edildiği gözlemlenmektedir. Bu doğrultuda edilen bulgular, küreselleşme ve kitle kültürü bağlamında da tartış1labilir. İçli’nin (2001: 166) belirttiği gibi, küresel kitle kültürü, televizyon, sinema, reklam gibi kültürel üretimin modern araçlarının egemenliğinde olup bu kültürün Batı merkezli olduğu söylenmektedir. Öte yandan eşitsizliklerin yeniden üretilmesine dayanan merkez ve çevre ülkeler ilişkisinin, merkez ülkelerin gelişimine katkı sunan bir sömürü ve bağlılık ilişkisine dayandığı da belirtilebilir (Dağtaş ve Yıldırım, 2018: 102). Buna göre sağlık ve sağlıkla ilişkili olarak bedene ilişkin göstergelerin de Batı merkezli bir çerçeveden yayıldığı söylenebilirken incelenen dergi kapaklarındaki kadınların da bu göstergeleri pekiştirici nitelikte olduğu görülmüştür.

Çalışmada ayrıca her iki ülkede yayınlanan dergi kapaklarında aynı görsellerinkapak kızlarının kullanılıp kullanılmadığı da incelenmiştir. 2009 yılında Amerika ve Türkiye'de yayınlanan Women's Health dergisinin üç sayısında kapaktaki kişilerin aynı olduğu bulgulanmıştır. 2010 ve 2011 yılında beş sayıda, 2012 yılında dört sayıda, 2013, 2014 ve 2015 yılında beş sayıda, 2016 yılında dört sayıda, 2017 yılında üç sayıda, 2018 yılında ise iki sayıda aynı kapak kızları kullanılmıştır.

Tüm bu bulgular ve değerlendirmeler sonucunda ise kısaca şunları söylemek mümkündür. Sağlık, yalnızca beden ile sınırlandırılamayan, ruhsal, sosyal ve fiziksel olmak üzere bütüncül olarak ele alınması gereken bir iyilik haline işaret etmektedir ve bu anlamıyla disiplinlerarası bir konudur. Sağlık üzerinde etkili olan pek çok faktörden bahsetmek mümkün olmakla birlikte kültürün de sağlığın tanımlanması açısından etkili olduğu aşikardır. Bu nedenle toplumlara ve kültürlere göre sağlık algısında çeşitli farklılıklar olabilmekle birlikte küreselleşmenin her alanda hissedilen etkileri, burada da gözlemlenmektedir. Küreselleşmenin, küresel bir kültür yapısı üzerindeki etkisi ve toplum ile bireylerin giderek birbirine benzeştikleri söylemi, sağlık açısından da değerlendirilebilir. Özellikle küresel bir yayılıma sahip olan popüler iletişim araçlarının bu süreçte önemli rolleri olduğu görülmektedir. Bu çalışmada da popüler dergilerden biri olan ve uzun yıllardır yayınlanan bir derginin her iki ülkedeki yayınları sağlığın boyutları ve kültürel farklılıklar ekseninde incelenmeye çalışılmıştır. Çalışma sonucunda, sağlığın daha çok fiziksel görünüm ve beden üzerinden açıklanmaya çalışıldığı ve benzer içerik ve konu başlıklarının her iki ülkede de yaygın olduğu sonucuna varılmıştır. Bu durum, sağlık açısından da kültürel farklılıkların giderek silikleştiğinin ve küresel bir anlayışın egemen olmaya başladığının göstergesi olarak okunabilir. 


\section{Kaynaklar}

Adler, N., \& Ostrove, J. (1999). Socioeconomic Status and Health: What We Know and What We Don't. Annals of the New York Academy of Sciences, 896(1), 3-15.

Akın, G. (2014). İnsan Sağlı̆̆ ve Çevre Etkileşimi. Ankara Üniversitesi Dil ve Tarih-Coğrafya Fakültesi Dergisi, 54(1), 105-116.

Alvarez, G., \& Ayas, N. (2004). The impact of daily sleep duration on health: a review of the literature. Progress in cardiovascular nursing, 19(2), 56-59.

Aubrey, J. (2010). Looking Good Versus Feeling Good: An Investigation of Media Frames of Health Advice and Their Effects on Women's Body-related Self-perceptions. Sex Roles, 63, 50-63.

Beck, U. (2002). The Terrorist Threat World Risk Society Revisited. Theory, Culture \& Society, 19(4), 39-55.

Bolsoy, N., \& Sevil, Ü. (2006). Sağlık-Hastalık ve Kültür Etkileşimi. Atatürk Üniversitesi Hemşirelik Yüksekokulu Dergisi, 9(3), 78-87.

Bulut, S. (2013). Sağlikta sosyal bir belirleyici; fiziksel aktivite. Türk Hijyen ve Deneysel Biyoloji Dergisi, 70(4), 205-214.

Büyüköztürk, Ş., Kılıç Çakmak, E., Akgün, Ö., Karadeniz, Ş., \& Demirel, F. (2016). Bilimsel Araştırma Yöntemleri. Ankara: Pegem.

Cirhinlioğlu, Z. (2012). Să̆lık Sosyolojisi. Ankara: Nobel.

Collier, R. (2018). Containing health myths in the age of viral misinformation. CMAJ, 190(19), E578.

Conlin, L., \& Bissell, K. (2014). Beauty ideals in the checkout aisle: Health-related messages in women's fashion and fitness magazines. Journal of Magazine \& New Media Research, 15(2).

Dağtaş, E. \& Yıldırım, O. (2018). Kültürel Emperyalizm Çerçevesinde Tüketim Pratiklerinin Türkiye Basınındaki Yansımalarının Çözümlenmesi: 24 Kasım 2017 "Kara Cuma” Örneği. Global Media Journal TR Edition, 9(17), 96-127.

Das, S. (2003). Harmful health effects of cigarette smoking. Molecular and Cellular Biochemistry, 253, 159-165.

Galderisi, S., Heinz, A., Kastrup, M., Beezhold, J., \& Satorius, N. (2015). Toward a new definition of mental health. World Psychiatry, 14(2), 231-233.

Giddens, A., \& Sutton, P. (2018). Sosyolojide Temel Kavramlar. Ankara: Phoenix.

Helman, C. (2007). Culture, Health and Illness. CRC Press.

Hofstede, G. (2001). Culture's Consequences: Comparing Values, Behaviors, Institutions and Organizations Across Nations. California: Sage. 
James, W., Nelson, M., Ralph, A., \& Leather, S. (1997). Socioeconomic determinants of health: the contribution of nutrition to inequalities in health. Bmj, 314(7093), 1545.

Jia, H., \& Lubetkin, E. (2005). The impact of obesity on health-related quality-oflife in the general adult US population. Journal of Public Health, 27(2), 156-164. 172.

İçli, G. (2001). Küreselleşme ve Kültür. C.Ü. Sosyal Bilimler Dergisi, 25(2), 163 -

Kaplan, M. (2011). Halk Tıbbının Kökenleri: Teşhisten Tedaviye Din ve Büyü İlişkisi. Milli Folklor (91), 150-156.

Keyes, C. (1998). Social Well-Being. Social Psychology Quarterly, 61(2), 121-140.

Koipysheva, E., Lebedinsky, V., \& Koipysheva, M. (2018). Physical Health (Definition, Semantic Content, Study Prospects). International Conference on Research Paradigms Transformation in Social Science (s. 601-605). Future Academy.

Kopelman, L. (2002). If HIV/AIDS is Punishment, Who is Bad? The Journal of Medicine and Philosophy: A Forum for Bioethics and Philosophy of Medicine, 27(2), 231-243.

Korn, L., Gonen, E., Shaked, Y., \& Golan, M. (2013). Health Perceptions, Self and Body Image, Physical Activity and Nutrition among Undergraduate Students in Israel. PloS one, 8(3), e58543. Sage.

Krippendorff, K. (2013). Content analysis: An introduction to its methodology.

Landrine, H., \& Klonoff, E. (1994). Cultural Diversity in Causal Attributions for Illness: The Role of the Supernatural. Journal of Behavioral Medicine, 17(2), 181-193.

Lesser, L., Mazza, M., \& Lucan, S. (2015). Nutrition myths and healthy dietary advice in clinical practice. American Family Physician, 91(9), 634-638.

Luyster, F., Strollo, P., Zee, P., \& Walsh, J. (2012). Sleep: A Health Imperative. Sleep, 6(1), 727-734.

MacLachlan, M. (2004). Embodiment: Clinical, critical and cultural perspectives on health and illness. England: Open University Press.

MacLachlan, M. (2006). Culture and Health: A Critical Perspective Towards Global Health. West Sussex, England: John Wiley \& Sons.

Malkin, A., Wornian, K., \& Chrisler, J. (1999). Women and Weight: Gendered Messages on Magazine Covers. Sex Roles, 40(7/8), 647-655.

Miles, L. (2007). Physical activity and health. Nutrition bulletin, 32(4), 314-363.

Neuman, W. (2014). Basics of Social Research: Qualitative and Quantitative Approaches. Pearson/Allyn and Bacon.

Okay, A. (2014). Sağlık İletişimi. İstanbul: Derin Yayınları. 
Öncel, S. (1997). Kültürel Yapı ile Sağlık-Hastalık İlişkisi. Ege Üniversitesi Hemşirelik Yüksek Okulu Dergisi, 13(1-3), 177-184.

Özen, S. (1993). Sosyolojide Bir Alan: Sağl1k Sosyolojisi ve Sağlık-Toplumsal Yapı İlişkileri. Sosyoloji Dergisi(4), 73-88.

Ravindran, N., \& Myers, B. (2012). Cultural Influences on Perceptions of Health, Illness, and Disability: A Review and Focus on Autism. Journal of Child and Family Studies, 21, 311-319.

Skalski, P., Neuendorf, K., \& Cajigas, J. (2017). Content Analysis in the Interactive Media Age. K. Neuendorf içinde, The Content Analysis Guidebook (s. 201-242). Sage.

Solak, Ö., Ulaşlı, A., Çevik, H., Dikici, A., Devrimsel, G., Erkol İnal, E., . . . Dündar, Ü. (2015). Romatizmal Hastalıklarda Tamamlayıcı ve Alternatif Tıp Yöntemlerine Başvuru. Kocatepe Tip Dergisi, 16, 116-121.

Strauss, J., \& Thomas, D. (1998). Health, Nutrition, and Economic Development. Journal of Economic Literature, 36(2), 766-817.

Sturm, R. (2002). The Effects Of Obesity, Smoking, And Drinking On Medical Problems And Costs. Health affairs, 21(2), 245-253.

Swiatkowski, P. (2016). Magazine influence on body dissatisfaction: Fashion vs. health? Cogent Social Sciences, 2, 1250702. Epsilon.

Tavşancıl, E., \& Aslan, A. (2001). İçerik Analizi Ve Uygulama Örnekleri. İstanbul:

Thoits, P. (2010). Stress and Health: Major Findings and Policy Implications. Journal of Health and Social Behavior, 51(S), S41-S53.

Tognetti, M. (2014). Social Health. A. C. Michalos içinde, Encyclopedia of Quality of Life and Well-Being Research (s. 6069-6070). Springer.

U.S. Department of Health and Human Services. (2009). Weight-loss and Nutrition Myths How much do you really know? https://www.umassmed.edu/contentassets/5fa 881 84f3a441e7b61ac8e256ea5ef7/myths.pdf adresinden alınd1

Ulutürk, S. (2015). Sağlık Ekonomisi, Sağlık Statüsü, Sağlığın Ölçülmesinde Kullanılan Ölçütler ve Önemi: Türkiye Örneği. Finans Politik \& Ekonomik Yorumlar, 52(603), 47-63.

Vaillant, G. (2012). Positive mental health: is there a cross-cultural definition? World Psychiatry, 11(2), 93-99.

Veenhoven, R. (2008). Healthy happiness: effects of happiness on physical health and the consequences for preventive health care. Journal of Happiness Studies, 9, 449469.

Vingilis, E., Wade, T., \& Adlaf, E. (1998). What Factors Predict Student Self-Rated Physical Health? Journal of Adolescence, 21(1), 83-97. 
Warburton, D., Nicol, C., \& Bredin, S. (2006). Health benefits of physical activity: the evidence. CMAJ, 174(6), 801-809.

WHO. (2020a). What is the WHO definition of health? https://www.who.int/about/ who-we-are/frequently-asked-questions adresinden alındı

WHO. (2020b). Mental health: strengthening our response. https://www.who. int/news-room/fact-sheets/detail/mental-health-strengthening-our-response adresinden alınd1

Araştırmacı Katkı Oranı: Araştırmacılar çalışmaya eşit oranda katkı sunmuştur.

Destekleyen Kurum/Kuruluşlar: Herhangi bir kurum/kuruluştan destek alınmamıştır.

Çıkar Çatışması: Herhangi bir çıkar çatışması bulunmamaktadır. 